\title{
Interview med Peter Brückner
}

Dette er en lettere redigeret udgave af en samtale med Peter Brückner $i$ foråret 1975 på foranledning af den artikel Brïckner sammen med Gabriele Ricke har skrevet „Om den astetiske opdragelse af menneskene $i$ arbejderbevagelsen" (Poetik 25). Rolf Reitan og Carsten Thau.

Brückner: Gabriele Ricke, sammen med hvem jeg har skrevet denne artikel, er adjunkt ved universitetet i Hannover og har lavet statseksamensarbejde om de ugeblade der henvender sig til arbejderklassen, iøvrigt et arbejde som jeg har skrevet et forord til, hun stammer fra det gamle SDS og kan regnes for en af de ikke-dogmatiske venstreorienterede i Hannover. At vi har skrevet denne artikel sammen er opstået rent tilfældigt i forbindelse med at bidragyderne til bogen på Wagenbach ${ }^{1}$ trådte sammen og meddelte hinanden, hvad vi kunne tænke os at arbejde med og jeg sagde, at det ville interessere mig at lave noget om arbejderklassens kulturelle arv. Da vi havde ret lidt tid, blev der spurgt, hvem der kunne tænke sig at være med; det kunne Gabriele og så lavede vi det ...

Sp: Du har sagt at denne talen om den kulturelle arv og denne insisteren på en overtagelse af den kulturelle arv delvis har noget for sig, hvordan mener du det?

Brückner: Dermed mener jeg ... lad mig sige det således, vi vinder jo som intellektuelle også vor politiske identitet igennem, at vi lærer eller forsøger at løse vor egen tilværelseshistories gåde, at vi med vor situation, med vore erfaringer, begriber den inden for en historisk referenceramme ... dette som det første. Det andet forhold beror på, at historien er en klassekampenes historie, det betyder at der findes en flerhed af socialrevolutionære traditioner $\mathrm{i}$ denne historie. Til disse socialrevolutionære traditioner hører ikke blot folk som Münzer og bondekrigene, men man kan også gå længere tilbage, til det ny testamente og profeterne og $\mathrm{i}$ det gamle testamente, her tales der tilbagevendende for bestemte 
socialrevolutionære traditioner. Altså, tilegnelsen af en kulturel arv kan, hvordan skal jeg sige det, for en revolutionær intelligens, for folk med et behov for en teori med revolutionært perspektiv, folk som er engagerede og som deltager i en omvæltning, for os kan tilegnelsen af en kulturel arv ikke betyde andet end fornyet gentilegnelse af alle disse socialrevolutionære traditioner $\mathrm{i}$ vor historie og $\mathrm{i}$ vor forhistorie, som jo vedvarende for såvidt angår den revolutionære interesse er blevet integreret, undertrykt eller simpelthen pulveriseret ud af historien. Således kan man sige: tilegnelse af arven betyder, som Walter Benjamin har benævnt det, at rive de socialrevolutionære traditioner ud af den altomklamrende konformisme i de borgerlige institutioner. Men det betyder tillige, at denne tilegnelse af en arv, set $\mathbf{i}$ forhold til den yngre historie, må være en tilegnelse af den borgerlige kulturs kritik af sig selv, men ikke må være en tilegnelse af denne kulturs „kanon“ om sig selv.

Når man læser vidnesbyrd fra DDR ... jeg kan kun sige, jeg er bestyrtet over i hvor høj grad dér, i fortsættelse af gammel kommunistisk sædvane, dette forhold præcist vendes om, således, at det der tilegnes, er det til enhver tid klassisk kanoniserede, det som det borgerlige samfund selv betegner som dets kultur, dets kunst.

Jeg er jo som I ved psykolog, og er måske som følge deraf meget interesseret i biografier. Når jeg f. eks. beskæftiger mig med kommunister som Karl Liebknecht, en mand som jeg sætter megen pris på, ... når f. eks. Liebknecht fra felten skriver til sine børn, så bemærker man, at han har de samme kulturelle traditioner som Sigmund Freud. Med den forskel, at de hos Freud som følge af hans formue var noget mere luksuriøse og bredere. Der hvor kunstnere, hvadenten de er forfattere, malere eller musikere, bliver forskrækkede over det implicitte barbari i den borgerlige kultur, eller hvor de formulerer kritik over for dette borgerlige samfund, eller hvor de sprænger den klassiske kulturs kanon og former, overalt hvor det sker står ideologerne fra det kommunistiske parti og siger: forfærdeligt!

Sp: Hvorfor?

Brückner: Ja, hvorfor? Min tese er, at det i forskellige socialdemokratiske og kommunistiske partier er blevet erkendt, at den borgerlige kunst, skal vi sige ..., har en bestemt socialt stabilise- 
rende betydning, den har altid været fungibel i beherskelsesøjemed. Det har endnu en anden årsag: hvilket koncept om politik man har; om det selv endnu er forpligtet over for den borgerlige adskillelse af sanselighed og fornuft. Når man har et koncept om politik, hvorefter politik i grunden er et spørgsmål om hoved og vilje og intet andet, da opstår naturligvis spørgsmålet: hvad gør jeg med følelserne? Da behøves der åbenbart for følelserne et selvstændigt kontrolsystem, og dette kontrolsystem kan bero på kunsten som æstetisk opdragelse.

$S p$ : Men aldrig en opdragelse udgående fra arbejderklassen og de lavere lag, eftersom kunsten iflg. borgerlig opfattelse aldrig var et anliggende for arbejderklassen?

Brückner: Nej, når man læser DDR-tidsskrifter vil man bemærke at millioner af arbejdende mennesker arbejder bedre, og lettere kan udholde deres tilværelse, efter at Beethoven har skrevet sin Eroica ...

$S p$ : Du siger, hvad der nok er rigtigt, at kunsten i DDR ikke har nogen anden funktion end en legitimationsfunktion.

Brückner: Nej, ingen anden ...

$S p$ : Den har heller ingen anden funktion i forbindelse med organiseringen af følelserne?

Brückner: Her må vi naturligvis sondre. Jeg vil sige, man kan helt ud forstå nogle af de kommunistiske partiers kulturpolitik, som fortsættelsen af den tyske overlærers eller lektors kulturelle formidling. Det politiske koncept hos statspartiet er helt igennem pædagogisk, og naturligvis tager folkeskolelæreren eller gymnasielæreren fejl, hvad angår den virkelige funktion af det, som han fremlægger af kunst eller moral for sine elever. Nuvel, på det realanalytiske plan kan meget naturligvis se anderledes ud ..., men det $g \varnothing \mathrm{r}$ en forskel om statens og administrationens organer står for en kanonisering af kunst eller ej. Det gør af den grund en forskel, fordi denne gestus af kanonisering og harmoni, eksempelvis også gøres gældende over for den skrivende arbejder. Når Ulbrecht i Bitterfelt til den ende siger, at det for os drejer sig om en sammensmeltning af Weimar og Bitterfelt ... Hvor ideologisk dette udsagn end må være, så viser det, at ikke blot kunsten, men også propagandaen for en borgerlig kunsttradition skal foregå inden for rammerne af kanoniserede produktionsforhold.

Forstår I, som følge af dette er det ikke blot sådan noget som 
en ideologisk krummelure, som man fra et realanalytisk synspunkt ikke behøver at bekymre sig om, derimod st $\varnothing$ der vi her på et opdragelsesinstrument, som i kanoniseringen af den borgerlige kunst og i denne fordrejede tese om den kulturelle arv tillige begrunder sin beredvillighed til for sit vedkommende at kanonisere produktionsforholdene, og skal vi sige, den samlede klassesituation.

Sp: Hmmh. Jaah.

Brückner: Vi diskuterer for tiden tidsskriftet „Forum“, det er et organ for lederne af Freie deutsche Jugend, som bl. a. forholder sig til ungdommens andelige problemer. Til stadighed st $\varnothing$ der vi på professorer og højere funktionærer, som i dette tidsskrift eksempelvis argumenterer med Goethe, eller man citerer i bestemte sammenhænge breve fra Ernst Thälmann, som han fra det fascistiske fængsel skrev til sine børn og hvori det hedder: „Goethe siger ...", ,allerede Goethe har sagt ...", ikke sandt, deraf kommer der sådanne trivialiteter som, „Skæbnen vil at vi kæmper"... Jeg ved ikke om jeg rigtig kan gøre klart hvad jeg mener, der bliver igen og igen, i pædagogisk фjemed, på grundlag af det borgerlige samfunds såkaldte klassikere fabrikeret moralske og pædagogiske ekstrakter, som i sig selv er udtalt umarxistiske. Man må tage højde for, at der $i$ året 1974 anføres et brev fra en kommunist til hans datter, som med pædagogisk hensigt citeres inden for FDJ med sætninger af typen: „Skæbnen vil kampen, skæbnen fordrer kampen, skæbnen tvinger os til kamp ..." Jeg troede det var produktionsforholdene, jeg troede det var værdiabstraktionen, der tvinger os til kamp, men dog ikke nogen skæbne ... Forstår I, det er jo den fordømte ejendommelighed ved den kanoniserbare, borgerlige kunst, at den trækker et mystisk slør over virkeligheden.

$S p$ : Hvis vi historisk forfølger dette, så gælder det også for Lukacs, der måske eksemplarisk repræsenterer denne linje fra Mehring. Også Lukacs har en pædagogisk og, så at sige, socialpsykologisk intention med sin kunstopfattelse, denne katharsiske funktion, der skaber en fascination ..., men hans egentlige hensigt er en politisk, fordi han som politisk tænker typisk er allianceorienteret og altid medtænker, at for arbejderklassen er det nødvendigt at udvikle alliancer med mellemlag, middelstanden, bønderne osv. Og dersom disse alliancer politisk skal vare fungible, da 
må også kulturpolitikken sigte mod, at man ikke skræmmer disse grupper bort. Kan man ikke sige, at denne historiske nødvendighed har sat et "traumatisk spor" $\mathrm{i}$ arbejderbevægelsens historie? Heri kan man måske se en årsag til aversionen eller den allergi over for de venstreintellektuelle, inden for Bund proletarischer Schriftsteller og i KPD, som gjorde sig gældende i Weimarrepublikken. Kan meget af dette ikke ses i perspektiv af kampen imod de venstreintellektuelle? Historisk betragtet?

Brückner: Tjah ... Hvorfor har mon Gertrud Alexander i Rote Fahne råbt til samling over for Piscators eksperimenter? Hvorfor har andre kommunister på den tid klaget over, at der findes gode kammerater, politisk helt igennem på den rigtige linje, men som i deres følelser og stemninger er udsat for bourgeoisiets påvirkninger igennem kunst og litteratur. Det forekommer mig, at vi må skelne mellem dette allianceaspekt, som I sikkert med rette fremhæver hos Lukacs, på den ene side, som stadig kan spille en rolle $\mathrm{i}$ den reale socialismes statsdannelser, og, på den anden side, de specifikke opfattelser af klasse, klassebevidsthed og politik, som selv ikke ved i hvor høj grad de selv er arvtagere af en borgerlig tradition, og - for det tredie - et eminent behov for magtud $\varnothing$ velse, som a priori orienterer sig mod social integration, homogenitet ... I den forstand drejer det sig ikke blot om de venstreintellektuelle: Ungdomsorganisationerne, Komsomol eller FDJ, må for Guds skyld ikke blive til rolige haver. Dvs. deres politiske opgave må til stadighed defineres sådan, at den ikke tangerer de til enhver tid siddende fagbestemte autoriteter. For at nævne et konkret eksempel, et FDJ-medlem der studerer, har så at sige to chefer, på den ene side universitetslæreren, rektoren og den videnskabelige vejleder, hvis krav man skal stræbe efter at opfylde og tage vare på, og, på den anden side, ungdomsorganisationen, som har en bestemt politisk opgave. Og det er nu af højeste vigtighed, at denne politiske opgave vedvarende er underordnet de faglige autoriteter. Det drejer sig om forhold, hvor det ikke blot er de venstreintellektuelle som der kæmpes imod, men der kæmpes mod enhver umiddelbar kærlighed til arbejderklassen. Kender I Shaws version af den Hellige Johanna? Der forekommer en ærkebiskop, som siger til Johanna: „Mit barn, du er forelsket i religionen!" og som lader forstå, at en uformidlet kærlighed til Gud altid allerede er kætteri, den må formidles 
via kirken. Sådan er det også her. En hvilken som helst kærlighed til arbejderklassen, må altid funktionæragtigt formidles via partiets autoritet. Tilsvarende må kærligheden til videnskaben altid formidles via den højere læreanstalts lærerkollegium etc. Forstår I, der findes et kompliceret system af hierarkier, i hvilken sammenhæng også den borgerlige kunsts kanonisering og tesen om den kulturelle arv fungerer, hvor beskeden dens betydning end må være, og som man ikke længere kan forklare eller besvare med kampen mod de venstreintellektuelle.

$S p$ : Vil du frakende den borgerlige kulturarv frigørende betydning overhovedet?

Brückner: Der gives endnu en årsag til, at tesen om den kulturelle arv spiller så stor en opdragelses- og uddannelsesmæssig rolle i den reale socialismes kulturpolitik. Til den ende har jeg sat det lille historiske kapitel foran $\mathrm{i}$ min artikel. I anden halvdel af det 19. årh. drejede det sig endnu om i en eller anden forstand at tilkæmpe arbejderen en akcepterbar plads inden for det borgerlige samfund. Man behøver blot at påtænke, at man omkring 1880 ved de tyske lærerseminarier ikke lod de kommende folkeskolelærere beskæftige sig med Goethe og Schiller. Det skulle der ikke undervises i i Folkeskolen, det var reserveret for børnene fra middellagene. Man behøver kun at tænke på den slags forhold og det bliver umiddelbart klart for én, at engang må denne tilegnelse af den borgerlige kultur have haft en klassekampsmæssig og emancipatorisk side.

Der findes i den reale socialisme en tendens til at kanonisere udvalgte dele af ens egen historie, og så derfra - fra ens egen tradition - at tage denne opfattelse af det emancipatoriske ved tilegnelsen af den borgerlige arv, hvor den forlængst har mistet den emancipatoriske betydning den havde i det 19. årh.

Sp: Det dilemma som din artikel munder ud i synes at tage sig ud som følger: på den ene side findes der en programmeret realistisk, socialistisk kunst, der ikke har nogen revolutionær eller progressiv funktion i sammenhæng med organiseringen af følelserne, og som næsten kan siges udelukkende at have en ideologisk funktion $\mathbf{i}$ den reale socialismes lande. Dilemmaet består $\mathbf{i}$, at den eneste kunst som vi i denne fase kender, måske er den såkaldte avantgardistiske kunst i dens forskellige udformninger. Men denne kunst er så svært tilgængelig, at den ikke har noget 
publikum blandt arbejdere og håndværkere. Du taler iøvrigt (i artiklen) ikke om fænomener som Brechts proletariske teater, eller andre former for proletarisk teater, du taler heller ikke om det potentiale, der eventuelt ligger $\mathrm{i}$ forskellige former for underholdning, de forskellige medier osv. Ligger der deri en indikation af hvorledes dilemmaet kan løses?

Brückner: - - - !!

$S p$ : Til det første punkt kan tilføjes, hvad du berører i forbindelse med citatet fra Adorno: „Og dog kan kunst - i hvert fald bortset fra revolutionære situationer $\mathrm{i}$ begrebets snavrere forstand - kun opfylde en kritisk funktion for såvidt som - og $\mathrm{i}$ bedste fald - den indeholder et moment af modstand over for samfundets tilstand, som værende ikke-identisk." - Men hos Adorno forholder det sig jo som bekendt sådan, at kunsten for at fastholde dette moment af noget ikke-identisk må udtrykke sig i esoteriske former, må overvintre i små esoteriske nicher, som i den modernistiske kunst af Kafka, Webern, Alban Berg etc.

Brückner: Ja, for det første mener jeg, at der her faktisk er et hul i mine overvejelser i den lille artikel, et ,hul" som I med rette gør mig opmærksom på, og som i realiteten også repræsenterer en indvending imod min artikel, fordi den sådan som den indgår $\mathrm{i}$ hele bogens sammenhæng er for ideologikritisk. Men til selve spørgsmålet ... egentlig har jeg formuleret dette dilemma en smule ironisk, også citatet fra Adorno er endda fra min side ment lidt ironisk. I kan forstå det som et udtryk for fortvivlelse, nemlig min svindende tro på, om kunst overhovedet betyder noget, hvadenten den optræder som 'kanoniseret', eller i Adornos forstand 'esoterisk'. Jeg har også konstrueret dette dilemma en smule plat, thi hvordan ser det egentlig ud med alle disse andre anstrengelser ... Anton Webern har som bekendt i Østrig arbejdet overordentlig meget med arbejder-musikforeninger, ligesom en Jugend-stil kunstner, med sin egen esoterik, Horst VoglerWede $f \varnothing r$ 1. Verdenskrig arbejdede med arbejderuddannelsesforeninger. Disse var forsøg, fra hvilke lidet historisk er opbevaret, men det var dog enkeltinitiativer, der har vist, at gennemsnitsborgerens barriere, der også er arbejderens og håndværkerens barriere, over for bestemte elementer i den moderne kunst - ikke er noget ontologisk. Jeg mener også at måderne at se og høre på, reaktionerne på kunst, er del af en falsk bevidsthed, om 
hvilken man ikke altid skal sige, at vi må tage den for givet. Hvem g $\varnothing$ r egentlig endnu den slags fors $\varnothing \mathrm{g}$, hvor påtager folk sig endnu det store besvær der er forbundet med bredere at formidle denne esotoriske kunst? Derimod kommer der altid noget „pædagogisk“ ud af det, at gøre en smule af en anden kunst mindre højtideligt krævende for arbejdere ... Så talte du om det proletariske teater. Nuvel, hvad blev der af Tretjakovs fors $\emptyset \mathrm{g}$ ? Hvor forblev Piscator? Hvilke chancer var der for Brecht i DDR? Hvordan er hans lærestykker blevet forstået? Eller jeg tænker på de endeløse diskussioner vi har haft om gadeteater. Jeg svinger her mellem to ekstremer. Min egen forestilling er, at der åbenbart gives specifikke objektive samfundsmæssige situationer, i hvilke kunsten hvordan det end nærmere forholder sig, har en emancipatorisk eller revolutionær virkning. Tænk på teatret og dets betydning for den franske revolution. Tænk på folk som Majakovskij med hans plakater og hans hamrende vers i den russiske revolution. Eller tænk også på den betydning, som bestemte æstetiske udtryk har haft i studenterrevolterne, især i den for hundrede-millionte-gang-citerede revolte i maj 1968. Godt, i sådanne situationer kan kunst på én gang - også i massemålestok - udøve en revolutionerende og underst $\varnothing$ ttende virkning. Dette er det ene som synes mig sikkert. Men det andet forhold som også synes mig sikkert, er at kunstens betydning for humaniseringen af de mellemmenneskelige relationer, når man betragter den virkelige historie, på en bestyrtende måde synes at være forsvindende lille. - Mange af os har i de sidste år under fascismen, da vi mærkede, hvad der var fat - og mange først bagefter - haft den opfattelse, at alene eksistensen af koncentrationslejre har f $\varnothing \mathrm{rt}$ kunsten og dannelsen ad absurdum. Og dengang var der en række mennesker, som havde den opfattelse, at efter Auschwitz kan man ikke længere skrive digte. Imidlertid er der siden forlængst skrevet digte, teaterstykker ... Selv holder jeg af musik, af Schönberg, beat, og må dog på samme tid sige, at ingen af de forhåbninger, som en eller anden har sat til kunsten, nogetsteds er blevet indløst anderledes end i denne mere eller mindre stille esotoriske nydelse, som jeg har, når jeg for mit vedkommende hører et stykke af Webern, om muligt med den adornoske analyse som baggrund.

Forstår I, jeg er fortvivlet over kunstens betydning, over be- 
tydningen af dannelse overhovedet og - mellem os sagt - også over betydningen af videnskab ...

$S p$ : Du talte om din egen forestilling, at kunsten i visse samfundsmæssige situationer kunne have en emancipatorisk revolutionerende betydning ...

Brückner: Ja og medvirke til mange menneskers selvinterpretation og evne til at udtrykke deres begejstring ...

$S p:$... i bestemte situationer. Dette kunne lede os til det begreb, eller til den topos vi benævner 'kulturrevolution'. Det ser ud som om mange af de politiske opfattelser der står til venstre for DKP kan sammenfattes i dette koncept, og at kritikken af Kominternpartierne er en kritik af deres manglende forståelse for nødvendigheden af en kulturrevolution. Måske du kan sige noget om dette i sammenhæng med „kunsten i denne specifikke samfundsmæssige situation"?

Brückner: Ja, spørgsmålet er, hvorfor kan kunsten i særlige situationer blive en medbevægende magt? Det forekommer mig at hænge sammen med - hvis jeg må have lov til at bruge et fysikalsk billede - at når der i revolutionære situationer ud af et koldt eller stivnet system bliver varme systemer, da udspiller der sig af- eller indsmeltningsprocesser, der er processer i den af historien producerede 2 , natur i mennesket, dvs. i det der passerer i den revolutionære bevægelse erkender jeg, idet jeg sammen med andre forandres, altså vi forandrer os selv, i og med dette åbnes der ikke blot for handlingsalternativer, der udvikler sig nye sansnings-, tænke- og følelsesmuligheder. Vi kan betegne dette som forandring af den menneskelige bevidsthed, eller vi kan betegne det som forandringen af mellemmenneskelige relationer, efter min mening to udtryk for den samme sag. Vi kan, om du vil, også betegne det som 'kulturrevolution'. Eller anderledes: kulturrevolution er for mig, som jeg nu ser det, et specifikt aspekt ved denne forandringsproces.

I bestemte samfundsmæssige situationer bliver den menneskelige bevidsthed, eller totaliteten af de menneskelige relationer sat fri som revolutionær produktivkraft. I sammenhæng med denne frisættelse af den menneskelige bevidsthed som revolutionær produktivkraft, sker der også noget på det område man betegner som 'kunst'. Jeg henviste før til Majakovskij; deri ligger der noget rigtigt, men også noget som leder på vildspor. Noget rigtigt 
for såvidt som en af kunstnere skabt kunst da kan vinde en bestemt revolutionerende betydning, takket forandrede sansningsog affektvaner hos de $\mathrm{i}$ forandringen deltagende individer. Noget vildledende ligger der, fordi - jeg vil udtrykke det meget emfatisk - ethvert menneske i den revolutionære proces fremstår som kunstner, og ikke længere 'kunstneren' som en særlig mennesketype. Udtrykket kulturrevolution indebærer imidlertid noget mere og også noget andet. Det står egentlig for et problem: forandringerne $\mathrm{i}$ ejendomsforholdene, eller en strukturel omvæltning af den $\emptyset$ konomiske basis frisætter på ingen måde en ny type menneskelig bevidsthed eller en ny type menneskelige relationer. Jeg mener, i studenterbevægelsen gik disse forhold indtil indf $\varnothing$ relsen af begrebet kulturrevolution, under begreberne socialiseringsstrategier og kommunikationsstrategier. Socialiseringsstrategierne var de egentlig, skal vi sige, politiske der sigtede imod forandring af ejendomsforholdene, ophævelsen af privatejendommen til produktionsmidlerne, medens kommunikationsstrategierne blev forstået som den revolutionære forandring af formerne for samkvem i det borgerlige samfund og med disse den menneskelige sanseligheds former. Og det forekommer mig, at i sammenhæng med disse kommunikations-teoretiske aspekter af revolutionære forandringer er det som kunst og kultur betyder noget mere snævert.

$S p$ : I forbindelse med denne problematik kunne du måske klargøre et muligvis dunkelt punkt i din artikel om forholdet mellem psykoanalysen og den historiske materialisme, nemlig artiklen „Marx, Freud“2. Du anvender her flere gange Helmuth Reichelts udtryk ,den tvangsmæssigt overgribende samfundsmæssige objektivitet" (der Uberhang an gesellschaftlicher Objektivität), der hos Reichelt henholder sig til de kvasi-selvstændiggjorte $\emptyset$ konomisk/ sociale processer under den kapitalistiske produktionsmåde, den omstændighed, at individerne $\mathrm{i}$ det borgerlige samfund nok skaber deres egen historie, men ,ikke med vilje og bevidsthed“ etc. Du siger da videre, at denne kapitalismens 2 . natur indlejrer sig i menneskenes ,psykiske apparat" som deres 2 . natur og at denne har en inerti ind i det socialistiske samfund; at den ikke med et slag elimineres med forandringen af ejendomsforholdet til produktionsmidlerne, men selvstændigt må omformes gennem kommunikationsstrategiske anstrengelser. Nuvel, hos Reichelt kan 
man nok, ud fra kritikken af den politiske økonomi, begribe, hvad der menes med et „overhæng“ af samfundsmæssig objektivitet, men hvordan er dette „overhængende“ moment beskaffent for såvidt angår den subjektive faktor, som du udstrækker formuleringen til. En 2. natur, der, som du siger, ,forholder sig resistent over for revolutionens materielle magt"?

Brückner: Jeg knytter egentlig dertil to overvejelser. Det første er en nyinterpretation af begrebet Termidor (termidor var if $\varnothing$ lge den franske revolutionskalender den elvte måned, der $\mathbf{i}$ historien blev kendt som „rædselsmåneden“, revolutionens kriseperiode, red.), enhver revolution har en "termidor". Man kan betragte det sådan, at revolutionære til stadighed overraskes af produktet af deres aktiviteter, fordi der eksisterer en objektivitet, der, uden at de vidste det, kanaliserer deres aktivitet. Dette er det ene aspekt. Vi kan i dag sige, at jakobinerne og forskellige grupperinger $\mathrm{i}$ den franske revolution, ikke har gjort andet end at erstatte adelens herredømme med bankiernes herredømme. Vi kan post festum fastslå det. Men de er naturligvis blevet overraskede af det. Og dette moment af overraskelse og den omstændighed, at den revolutionæres produkt rives løs fra ham og klædes af synes mig at hænge sammen med det som Reichelt har beskrevet som Úberhang an gesellschaftlicher Objektivität.

Så er der endnu et andet aspekt: i høj grad i modsætning til Freud, der var tilbøjelig til historisk at almengøre psykoanalysens resultater, og at unders $\emptyset$ ge djævleneuroser fra det 16 . årh. med dens instrumentarium. I udtalt modsætning til Freud, der i de mekanismer som fører til neuroser ser noget ahistorisk, forekommer det mig, at der gives en historisk sammenhæng mellem det som vi betegner med det døde arbejdes herredømme over det levende arbejde, altså på den ene side den måde som den samfundsmæssige rigdom udarbejdes på, under kapitalismen og på den anden side den historiske tilblivelse af dette ubevidste og disse ubevidste mekanismer, som Freud handler i forhold til i sin teori. Hos Freud er, som man kan påvise, det ubevidste ikke noget ahistorisk - ikke som hos C. G. Jung noget artshistorisk altid-det-samme - derimod er det ganske tydeligt altid hos Freud historisk defineret. Således, at den hos individet efterviselige patogenese af den individuelle livshistorie, der af Freud betegnes som den uundgåelige kulturelle konflikt, der også fører til sådan 
noget som det forgangnes herredømme over nutiden, denne patogenese forekommer mig historisk, over mange formidlinger, at hænge sammen med opkomsten af den kapitalistiske produktionsmåde. Sådan at de samme historiske udviklinger, der producerer det af Reichelt beskrevne „overhæng“ af samfundsmæssig objektivitet, også fremkalder det til enhver tid specifikke herredømme fra det forgangne og de kulturelle ar i og over individets produktivkræfter, som Freud analyserer. Også af den grund forekommer mig forandringen af den menneskelige bevidsthed eller de mellemmenneskelige relationer - og jeg tror ikke man kan skille de to sider ad - at være uadskillelig fra forandringerne af den $\emptyset$ konomiske basis i samfundet. Forstår $\mathrm{I}$, når nu engang historisk det ene har betinget det andet, er der i mellemtiden, i hvertfald ud fra dette aspekt, sket en løsrivelse af formerne for det menneskelige samkvem og den menneskelige inderlighed fra produktionsforholdene, de er funktionelt blevet autonome. Derfor behøver de en selvstændig revolutionær omvæltning. Dette indbefatter jeg under kulturrevolution.

Sp: Og der kommer så også kommunikationsstrategierne ind i billedet. Men hvordan forestiller du dig at vi i dag anticipatorisk kan udvikle sådanne kommunikationsstrategier i de politiske bevægelser?

Brückner: Forstår du, nu spørger du mig hvordan kan vi fremstille den specifikke situation, i hvilken ... (fælles latter).

$S p$ : Du mener ikke der er mulighed for at producere eller konstruere en modkultur. Mener du, at det fuldstændigt afhænger af den specifikke situation? Man kan ikke planlægge en proletarisk subkultur eller modkultur i politisk øjemed?

Brückner: Så langt vil jeg ikke gå. Lad mig et øjeblik overveje, hvordan jeg egentlig tænker mig dette ... Jeg kan ikke ganske simpelt katapultere mig ud af min egen historie. Mine egne historiske erfaringer fortæller mig, at der var et bestemt tidspunkt, hvor det kommunikationsstrategiske aspekt og det samfundsstrukturelle [vergesellschaftungsmässige] aspekt skiltes ud fra hinanden, og det mod-samfundsmæssige aspekt ved en revolutionær bevægelse begyndte at forsvinde til noget subkulturelt - ordet degenerere bruger jeg ikke gerne - ihvertfald befandt det kulturrevolutionært kommunikationsstrategiske sig pludseligt som mod-samfundsmæssige øer i kapitalismen, helt frem til den 
absurde tilstand, hvor politiske hoveder begyndte at ernære sig af korn, selv at dyrke deres afgrøder eller lignende afsindigt, at tage stoffer osv. På den anden side har det samfundsstrukturelle aspekt tingsliggjort sig til de kommunistiske studenterpartier. Dette er noget af min historiske erfaring. På den anden side har det kulturrevolutionære, kommunikationsstrategiske aspekt udfoldet $\sin$ frugtbarhed og produktivitet i det $\varnothing$ jeblik, hvor det kunne forene sig med en allerede stedfindende tilegnelsesstrategi inden for studenterbevægelsen. Da studenterne begyndte med at tage statsborgerens pligter og rettigheder alvorligt ved Vestberlins universitet og kom ud i deres første konflikter med administrationen, og der pågik de første aktioner på universitetsområdet og i byen, på det tidspunkt fik de fra München og andre områder kommende, og gennem folk som Rudi Dutschke formidlede, kulturrevolutionære aspekter, med traditioner af situationistisk art og traditioner af evangelisk art, på én gang en chance for at blive politisk betydningsfulde.

$\mathrm{Nu}$, som et fors $\varnothing \mathrm{g}$ angående: hvad kan jeg i vurderingen af den nuværende situation stille op med dette? Jeg kan sige - og her taler jeg igen primært ud fra de tyske erfaringer - at vi, eller mange af os, er tvunget til en aktiv venten. 'Aktiv venten' betyder, at vente på en sådan måde, at vi vil være $\mathrm{i}$ den situation, at vi kan sanse chancerne når de byder sig, og, såvidt muligt, allerede at g $\varnothing$ re noget for at disse chancer igen indtræder. I denne sammenhæng mener $\mathrm{jeg}$, at visse modkulturelle anstrengelser helt igennem har deres værdi; i hvilken forbindelse vi igen må sondre: vi ved ikke hvilken betydning disse mod-kulturelle anstrengelser, som i dag findes i mange lande en dag vil have, vi kan så at sige ikke forudse det. Dette er den ene side og dette giver mig endnu ikke mod til at opstille en mod-kulturs konstitution. Det andet - og det gør mig ondt at jeg desværre ikke kan sige det mere komprimeret: udgående fra sammenhængen mellem organisation og bevidsthed ser jeg en hæmsko $i$, at så mange af os, i hvertfald i Tyskland, er beredte til at akceptere de borgerlige organisationsformer på universiteterne og på private områder. Selv didaktikken for kritikken af den politiske $\emptyset$ konomi forekommer mig at praktiseres uden en kritik af formerne for borgerlig interaktion, hvor selve didaktikken for kritikken af den politiske фkonomi efter min opfattelse naturligvis også skulle lig- 
ge i kritikken af formerne for interaktion i det borgerlige samfund. For såvidt gør vi ret $\mathrm{i}$ også for vort eget vedkommende, at indoptage mod-samfundsmæssige impulser; med alle de mådehold med hvilke, som jeg ser det, de historiske erfaringer forpligter os.

Sp: Vi har forud for denne samtale diskuteret labiliteten og det vedvarende potentiale af frigørende muligheder på forskellige områder i det kapitalistiske samfund og vi har også berørt dette kompleks, da vi tidligere snakkede om de ,ikke-identiske momenter“. Hvordan tror du disse i sig selv abstrakte indsigter kunne føre til overvejelser og udforskninger med et strategisk perspektiv? Hvis der virkelig findes en sådan labilitet, da må der også kunne findes strategier, der bringer denne labilitet ud af balance ...

Brückner: ??

$S p$ : Fra forskellige kilder har vi erfaret om den modstand der rejste sig i forbindelse med opførelsen af et atomkraftværk i Wyhl. Her dannedes en lang række aktionskomiteer bestående af et bredt udsnit af egnens befolkning, bønder, håndværkere, forretningsdrivende, arbejdere m. v. Såvidt vides var mere end $70 \%$ af disse mennesker forud for bevægelsen mod atomkraftværket, CDU/CSU-vælgere. Da det imidlertid viste sig, at deres holdning over for dette for dem så nære og pătrængende politiske spørgsmål ikke kunne artikuleres inden for de vante repræsentationsdemokratiske kanaler, reagerede de med at melde sig ud af CDU og i massemålestok sende deres partibøger retur. Dvs. at systemets demokratiske facade blev gennembrudt af disse mennesker i og med deres politiske erfaringer ...

Brückner: Ja, jeg ville erindre om noget lignende. Forstår I, det er naturligvis fatalt, men et universitetsmenneske falder det umiddelbart ind, at man må studere disse begivenheder nøjere. Jeg vil sige, vi har to opfattelser af politik, dels den borgerlige, der baserer sig på repræsentation og repræsentationsorganer, og dels en anden som man lidt vagt, og måske endda ikke så vagt, kan beskrive som en fremadskridende samfundsmæssigg $\varnothing$ relsesproces. Og nu mener jeg: vi skulle i første omgang åbent vende opmærksomheden mod sådanne felter i samfundet, på hvilke der begynder basisprocesser, som, blandt dem der deltager $\mathrm{i}$ disse processer, falsificerer ideen om repræsentationsorganer i borger- 
lig forstand. Det foregår jo, og jeg mener man kan henvise til andre eksempler, såsom bønderne i Lassac, man kan også pege på en række fænomener i de norditalienske byer, modstanden mod skattebetaling osv., man kan fremhæve bydelsarbejde og husbesættelser. Disse processer har i det sidste årti ligesom hobet sig op og vi kan også henregne studenterbevægelsen under dem. Det forekommer mig, at der i disse bevægelser fuldbyrder sig en selvkonstruktionsproces af en helt ny form for "klassebevidsthed" - som forskrift. Men forstår I, når I spørger mig hvilken strategi der følger deraf, så kan jeg i første omgang kun give det lunkne svar: lad os studere disse processer og prøve bedre at forstå, hvad der egentlig sker, og lad os overveje om ikke de mennesker der er gået igennem sådanne basisprocesser har ændret sig. Vi behøver nu sådan noget som en interventionsstrategi, for at afprøve, hvor langt disse forandringer går.

$S p$ : Men spørgsmålet var også tænkt som et spørgsmål om, hvilke perspektiver vi kan anlægge på sådanne interventioner. Hvorledes fortsættes sådanne erfaringer eller ",forandringer" hos de pågældende mennesker $\mathrm{i}$ en emancipatorisk retning. For at give et eksempel: måske kan denne historie om CDU-vælgerne forløbe således, at CDU tvinges til at modificere sin politik et stykke henad vejen og at bevægelsens deltagere derved integreres $i$ det gamle lort påny. Hvordan hindrer man ydermere, at denne politiske labilitet fixerer sig til højre. Hvad gør man for organisatorisk at fastholde emancipatoriske erfaringer i de periodisk, punktuelt forløbende borgerbevægelser?

Brückner: Ak ja, vi kan jo ikke udefra gå svangre med tanker om at organisere de mennesker der politiserer sig i sådanne basisprocesser, hvor sprogløse de end måtte være. Vi kan jo ikke gå hen og sige: Lad os organisere folkene fra Wyhl, eller fra Lip, Lassac eller i den dur! - vi bliver smidt ud.

Desværre blev samtalen afbrudt på dette tidspunkt, hvor vi søgte at indkredse organisationsspørgsmålet ud fra en principiel synsvinkel. Ad denne vej tænkte vi os at gribe tilbage til spørgsmålet om kommunikationsstrategierne samt spørgsmålet om kulturpolitikkens stilling i tilknytning til disse. Imidlertid forlod Brückner kort efter Danmark, og vi fik ikke lejlighed til at færdigg $\phi$ re interview'et $\mathrm{i}$ den omgang. 


\section{Noter:}

1. Bogen der sigtes til er „Das Unvermögen der Realität, Beiträge zu einer anderen materialistischen Ästhetik", af Peter Brückner, Gisela Dischner, Peter Gorsen, Alfred Krovoza m. fl., Verlag Klaus Wagenbach, Berlin 1974.

2. Står at læse i „Marxismus, Psychoanalyse, Sexpol“, bind 2, Fischer Bücherei, Frankfurt/M 1972. Dansk oversættelse i „Marxisme-Psykoanalyse“, Rhodos, Kbh. 1974. 